\title{
WORK CONTEXT IN THE AUTOMOTIVE INDUSTRY AND DAMAGE TO WORKERS HEALTH
}

\author{
Submission: 09/10/2017 \\ Accept: 22/12/2018 \\ Camila Brüning ${ }^{1}$ \\ José Henrique de Faria ${ }^{2}$ \\ Karlo Marques Junior ${ }^{3}$
}

\begin{abstract}
This paper analyzes the relationship between (i) worker's perception about their working context and (ii) the physical, social and psychological damage that they perceive having from working in this context. Data were collected in the production line of three factories of an automotive company situated in the metropolitan region of Curitiba/Brazil. The theoretical basis for the analysis is the Psychodynamics of Work (DEJOURS, 1993), through which the dynamics of suffering and illness of workers inserted in this context is analyzed. We conducted a descriptive case study with primary data collection by applying the Inventory of Work and IIIness Risk - ITRA (MENDES, 2007). The relationship between physical and psychosocial damage and the perception of workers in relation to their work environment were evaluated by a Tobit regression model. The results suggest that: a worsening in the workers rating of the working conditions leads to a higher incidence of illnesses. The results also suggest that variables such as "freedom of expression", "experiences of pleasure", "experiences of suffering" and "perception of recognition" are important to explain incidence of disease symptoms.
\end{abstract}

Keywords: Psychodynamics of Work; Work Context in the Automotive Industry, Tobit model.

\footnotetext{
1 Federal University of Paraná - Psychology Department: Professor of the undergraduate and graduate programs in Psychology. Curitiba, Paraná, Brazil. PhD in Administration from the Federal University of Paraná in the research line "Strategy and Organizational Analysis". Graduated in Psychology at the Federal University of Paraná. E-mail: camila.bruning@ufpr.br. ORCID: https://orcid.org/0000-0003-3869-3917

2 Federal University of Paraná - Professor of the Graduate Program in Administration and Technological Federal University of Paraná Professor of the Graduate Program in Administration. Curitiba, Paraná, Brazil, PhD in Business Administration from the University of São Paulo- FEA / USP and Post-Doctorate in Labor Relations from the Institute of Labor and Industrial Relations - ILIR - University of Michigan. President of the Brazilian Society for Organizational Studies - SBEO.

E-mail: jhfaria@gmail.com. ORCID: https://orcid.org/0000-0003-3971-7992

3 Affiliation State University of Ponta Grossa - Economics Department: Professor of the undergraduate and graduate programs in Economics. Country Ponta Grossa/ Paraná/ Brazil PhD in Economic Development from the Federal University of Paraná.

E-mail: karlomjunior@hotmail.com. ORCID: https://orcid.org/0000-0003-2656-2637
} 


\section{RESUMO}

Este trabalho analisa a relação entre (i) a percepção do trabalhador sobre seu contexto de trabalho $e$ (ii) o dano físico, social e psicológico que percebem ter ao trabalhar nesse contexto. Os dados foram coletados na linha de produção de três fábricas de uma empresa automotiva situada na região metropolitana de Curitiba. A base teórica para a análise é a Psicodinâmica do Trabalho (DEJOURS, 1993), através da qual se analisa a dinâmica do sofrimento e da doença dos trabalhadores inseridos neste contexto. Realizamos um estudo de caso descritivo com coleta primária de dados, aplicando o Inventário de Riscos de Trabalho e Doença - ITRA (MENDES, 2007). A relação entre danos físicos e psicossociais e a percepção dos trabalhadores em relação ao ambiente de trabalho foram avaliadas por um modelo de regressão de Tobit. Os resultados sugerem que: um agravamento na classificação dos trabalhadores das condições de trabalho leva a uma maior incidência de doenças. Os resultados também sugerem que variáveis como "liberdade de expressão", "experiências de prazer", "experiências de sofrimento" e "percepção de reconhecimento" são importantes para explicar este processo de saúde e doença.

Palavras-chave: Psicodinâmica do Trabalho; Contexto de trabalho na Indústria Automotiva; Modelo Tobit.

\section{INTRODUCTION}

Understanding the factors that lead to worker's illness is not an easy task. Identifying the links between damages in worker's health and the aspects they experience in their daily work is a growing demand for corporations that seek to take responsibility for the costs they externalize to their workers and society. Therefore, it is necessary to identify aspects of work in which it is possible to intervene to promote quality of life and health for workers (JACQUES, 2007).

In this sense, this research aims to identify relationships between aspects of the work context and physical and psychological damages to workers' health.

We choose to study a case of the automotive sector, seeking to analyze its work context, because the morbidity profile of workers in the automotive industry since the productive restructuring of this sector in Brazil has been characterized by a decrease in the occurrence of health problems due to typical work accidents and, in an opposite direction, an emergency and expansion of health problems such as chronic diseases like repetitive stress injury, cardiovascular and circulatory diseases, as well as psychic problems. This profile of chronic diseases in the working population is similar to that of the general population, but tends to occur earlier among these workers when compared to the general population (PINA; NAVARRO STOTZ; JACKSON FILHO, 2018). Also, this branch of the industry is traditionally a developer of management technologies that are disseminated and replicated in other industries (FARIA, 2017), which may be a predictor that other industries will adopt similar work context. In the region were this studied was carried out, in particular, the organization, and its 3 factories that are here analyzed, are considered highly influential in the dissemination of management practices to other industries, especially in its own production chain (IEL/NC, 2009).

The theme of worker's health in industrial work contexts in general, and in the work context of automotive industry in particular, has been addressed in several studies:

Landisbergis, Cahill and Schnall (1999) already warned about the impacts of lean production systems, which are characteristic of the work context the automotive industry, on workers' health. According to the researchers, innovative systems of work organization, such as lean production and total quality management, were introduced in industry to increase productivity, however, little is examined about the impacts of these systems on the health and subjectivity of workers. In their work, the authors conclude that there are relationships between the work context and the incidence of hypertension and cardiovascular disease, that there is little evidence to 
support the hypothesis that lean production "empowers" auto workers, on the contrary, evidences suggests that lean production creates intensified work pace and demands, which increases the incidence of musculoskeletal disorders.

In a more recent research, developed in Brazil, Pina and Navarro Stotz (2015) investigate the issue of Collective Health / Worker's Health, focusing on the dimension of work intensification and its relationship with health. The researchers analyze the process of intensification of work and its relation to workers health from the perception of the workers of "Mercedes Benz do Brasil" (Mercedes Benz of Brazil), located in São Bernardo do Campo. Their results shows that three dimensions of the work context in the automotive industry stand out as being related to illness processes: work rhythm, work extension, and management by stress. This study contributes to the advancement of the understanding of the intensification of work and its relation to health and, at the same time, it gives indications about the limits and the possibilities put to the collective action of the workers in the current historical conditions (PINA; Navarro Stotz, 2015).

In a paper later published in 2018, Pina, Navarro Stotz and Jackson Filho wrote that the productive transformations in Brazil since the 1990s have brought about changes in the social production of workers' wear and the epidemiological profile of workers. The researchers analyze the process of intensification of work and its relation to health from the perspective of the health-disease process and conclude that the work context identified reflects practices of work intensification, characterized by intense rhythm, work densities, prolongation of the journey and management by stress. Their research seeks to reflect on the need to advance the search for knowledge about the intensification of work and its relation with health (PINA; NAVARRO STOTZ; JACKSON FILHO, 2018).

In addition to providing a case study in a region different from the previously mentioned studies, the present research seeks to enrich the understanding of the relations between work context and illness by adopting as theoretical reference the Psychodynamics of Work.

A methodological innovation is also proposed: as will be discussed, empirical researches that use the Psychodynamics of Work tend to adopt almost exclusively qualitative methodological procedures. The few cases of researches in Psychodynamics of Work produced in Brazil that use quantitative methods, collect data using the Inventory of Work and Illness Risk - ITRA (MENDES, 2007), as did we, but perform only descriptive statistical analysis and factorial analysis. The proposal presented here aims to demonstrate how the data collected through this instrument allow the analysis of relationships between variables and identified factors using a Tobit regression model.

In order to deepen the research on the relationship between the work context in the automotive industry and its effects on the health and subjectivity of the workers included in it, we conducted a case study that was carried out in three factories of an automotive company located at the metropolitan region of Curitiba- Brazil.

In these three factories, we collected data on workers' perceptions of their work context, as well as the damages that they experienced in their health over the last 6 months. Data were collected with 361 employees of the company that is here called Gama.

Each employee responded to the Inventory of Work and Risks of Illness (MENDES, 2007). The inventory consists of 4 scales, with about 30 questions each. which were reduced in factors through factorial analysis (HAIR; ANDERSON; TATHAM; BLACK, 2005). The relationships between the factors that denote workers' perception regarding their work context and the factors that indicate physical and psychosocial damages to their health were analyzed through a Tobit regression model applied to censored dependent variables (BAUM, 2006; WOLLDRIDGE, 2011).

The analyzes presented here are based on the theory of Psychodynamics of Work (MENDES, 2007), which aims to explain the articulation between the work context and processes of subjectivation that can lead to worker's illness, such as different experiences of suffering and pleasure. 
This article is structured in the following way: first we present the theory of the Psychodynamics of Work. In the following section, we present the methodological procedures adopted for both data collection and data analysis. Then we present the regression analysis and its results. Finally, we present the research conclusions.

\section{PSYCHODYNAMICS OF WORK}

The Psychodynamics of Work is the theory through which we analyzed the articulation between the work context in the company under study and the physical and psychosocial damages to the health of the workers inserted in it.

The object of study of this theory is the dynamic relation between work context and processes of subjectivation of workers. By processes of subjectivation we mean the experiences of pleasure and suffering that workers report having in their work, processes of health and illness at work, as well as strategies workers adopt to mediate contradictions they experience in the organization of work (MENDES, 2007).

The Psychodynamics of Work focuses on the dynamic relationships between individual's psychological structure and the work context in which they are inserted (MENDES, 2007), including in this context the management technologies to which they are submitted (FARIA, 1997). The Psychodynamics of Work argues that experiences of pleasure and suffering can lead to health or illness, and that they are the result of three different dimensions (TAMAYO, 2004):

i. The subjectivity of each worker: that corresponds to the person as singular, with its history, desires and needs;

ii. The collectivity: that is, the interpersonal relations between equals and hierarchies, norms and values of social coexistence in the work

iii. The work context: which is characterized by the Psychodynamics of Work as the aggregate of three factors:

a. work organization: defined as the organizational norms that regulate work in an organization. Which includes the division of labor, the content of tasks, the power relations that involve the hierarchical system, the modalities of command and responsibilities (MENDES, 2007);

b. working conditions: defined as the physical, chemical and biological environment of work, as well as the conditions of hygiene, safety and the anthropometric characteristics of the work station (MENDES, 2007);

c. work relations: defined as all human relations originated in the work context, including relations with hierarchies, managers, supervisors, clients, external agents as well as other workers (MENDES, 2007).

The founder of the theory of Psychodynamics of Work, Dejours (1987, 1994, 1997 and 2000) argues that two types of contradiction may emerge from the confrontation between individual's psychicological structure and the work context in organizations: (i) a contradiction concerning the encounter between the imaginary impression produced by the subject, which is product of one's individual history, with the impression of reality, produced by the given work situation; (ii) a contradiction concerning the encounter between the diachronic impression (which is the individual's singular history, its past, its designs and desires), with the synchronous register (which is constituted by the material, social and historical context in which the work relation takes place). 
Dejours (2000) argues that a contradiction or incongruity between the diachronic and synchronic dimensions described above leads to suffering and can lead to mental and psychosomatic illness according to the organization of the personality of each individual. On the other hand, resonance between these registers enables pleasant experiences.

About the experiences of suffering, the Psychodynamics of Work understand that, having in its extremes the mental illness on one hand and the psychological well-being on the other, it can be said that two conditions are necessary in order for the work to permit a condition of equilibrium: (i) the first is that demands of intellectual, motor or psychosensory nature are in agreement with the capacities of the individual, and, so been, may be a source of pleasure; moreover, (ii) the content of the work must be a source of sublimatory satisfaction for the individual (DEJOURS, 1974, 2000).

The obstacle to sublimation occurs when there are no organizational conditions for the establishment of symbolic resonance. In this way, the subject cannot benefit from the work to dominate his suffering and turn it into creativity. When this happens, the only way out is the vicious circle in which suffering contributes to destabilizing the subject, impelling him to illness (DEJOURS, 2000).

According to Dejours $(1994,2000)$ the work context has broad effects on the psychological suffering, and can contribute to aggravate it, leading, possibly, to somatization and illness, or to subvert it in pleasure, contributing to a sense of well-being, to recognition and even to further development of one's self-esteem and identity.

Dejours (1997) argues that there are points of congruence between the diachronic and synchronic dimensions in the relation of the individual and the work context, which creates space for symbolic resonance. About symbolic resonance, the author clarifies: "it requires very particular conditions of agreement between the theater of reality and the inner theater of the individual's singular history ghost... it is necessary that the tasks have meaning for the subject, in view of its singular history" (DEJOURS, 1994, p. 134).

Through work, the subject engages in social relations, to which he transfers issues inherited from his past and from his affective history (DEJOURS, 1994). For this transfer to be activated in the encounter with the work situation, it is necessary that the tasks have meaning for the individual. In reliving this psychic theater, the subject seeks its self-realization, through recognition in the social field. "Recognition is the fundamental retribution to sublimation" (DEJOURS, 1997, p.158).

In a systematic review of the literature, Giongo and Monteiro (2015) affirm that Psychodynamics of Work has assumed an important role in the Brazilian studies on worker's health / mental illness.

In their research, the authors identified and analyzed 4 theses, 19 dissertations and 50 articles published in Brazilian journals that used the theory and / or method of Psychodynamics of Work between 2007 and December 2013 (GIONGO; MONTEIRO, 2015).

The authors identified that the majority of these researches were based on qualitative methods: 63 out of 70 papers analyzed, with only 4 of the 70 papers declaring to have used quantitative methods (GIONGO; MONTEIRO, 2015).

According to the authors the researches were mainly from publications in the field of Psychology, (46 studies), compared to a much timid publication of studies from Production Engineering (9 studies), Nursing (8 studies), Administration and organization studies (5 studies), Collective Health (3 studies), Physiotherapy / Occupational Therapy (2 studies), and Nutrition (1 study) (GIONGO; MONTEIRO, 2015). 
In addition, Giongo and Monteiro (2015) point out that the Brazilian research analyzed has, for the most part, the objective of investigating worker's experiences of pleasure and suffering, and that, in order to do that, they tend to carry out exploratory and descriptive researches. The authors point out as a result of their analysis, that the most studied professional category is health workers (GIONGO; MONTEIRO, 2015).

The work of Machado and Macedo (2016), which seeks to systematize and summarize the Brazilian production in Work Psychodynamics, corroborates similar findings. The authors identified and analyzed 95 articles that used the Psychodynamics of Work published in the Portal of Periodicals CAPES / MEC, in Portuguese language, from 2000 to 2014 and concluded that the researches tend to adopt qualitative methods and to prioritize the description and theoretical analysis of different work contexts and its relation with worker's health and suffering (MACHADO, MACEDO, 2016).

Soldeira (2016), also in an article that aims to systematize the methodology Psychodynamics of Work, writes that this theory allows to link a range of various techniques for research, such as individual interviews, collective interviews, scales, among others, aiming to broaden the psychodynamicist practice, in this view the main characteristic of research using Psychodynamics of Work is not so much a unique form of data collection or analysis, but a research that is allied to a practice that seeks to achieve the transformation of work context and is engaged with the workers' struggle for mental health (SOLDERA, 2016).

The results pointed out in these three systematizations Brazilian literature on Psychodynamics of Work demonstrate how the method originally proposed by Dejours (1993) has been adapted and has assumed contributions of different disciplines and methodologies in the Brazilian academy, including the use of various instruments of data collection and analysis.

The research presented here takes part on this understanding and assumes that studies using new instruments of data collection and analysis may contribute to increase the quality of research and analysis in studies based on Psychodynamics of Work, once it helps to identify and analyze empirical evidence that broadens the understanding of worker health in different organizational contexts. Hence the methodological choice adopted here, to proceed with a quantitative data collection and analysis, since the use of this type of methodology is still scarce in research based on Psychodynamics of Work.

It is important to emphasize that Mendes (2007) already proposed in her work the use of the Inventory of Work and Illness Risk - ITRA as a quantitative instrument of data collection in Psychodynamics of Work. The method of analysis proposed in this work, however, focuses mainly o the descriptive statistics analysis of the results obtained through the application of this instrument (MENDES, 2007). A contribution of the present work is the proposition of an additional form of analysis of the data that can be collected through the use of the same instrument, demonstrating that it is possible to explore relationships between the factors and variables accessed through a Tobit regression model.

In addition, it is important to note that the work context in the automotive industry has already been researched from the framework of the theory of Psychodynamics of Work, as can be verified in the research of Rancan and Giongo (2015). The authors' research is based on an exploratory, descriptive, essentially qualitative study that concludes that there is an intense process of suffering and risk of illness of the working people in this context, evidencing the need to problematize and rethink the relationships and the work configuration. In a similar sense, the present work aims to deepen the reflection about the identified relationships between work context and suffering, seeking to recognize which more specific aspects of the work context relate to which more specific aspects of suffering, and, if possible, which are the directions and forces of these relations. 


\section{METHODOLOGY}

From a technical perspective, this research is a descriptive and analytical case study, with a sectional temporal cut, that uses quantitative research methods. The level of analysis is organizational, since we analyze how characteristics of the organizational structure are related to the subjectivation processes of workers inserted in it, being the collective workers, therefore, the unit of analysis.

\subsection{Population and Sampling}

Regarding population and sampling, this research collected data from workers of the production lines of three factories of an automotive company located in the metropolitan region of Curitiba. The company is here called Gama, and each of its factories are called, respectively: GamaVP (a factory of production and assembly of passenger vehicles); GamaVU (a factory for production and assembly of utility vehicles), and GamaMo (a factory that produces automotive engines). A sample of 361 respondents was obtained, which allows a confidence level of $95 \%$ in relation to the total population. In relation to the three factories that participated in the research: for GamaVP, it was obtained a sample representing a total of $12.42 \%$ of its workers' population, for GamaVU a sample that represents $16.14 \%$ of its total population, and finally the GamaMO a sample of $18.10 \%$ of the total number of workers at this plant.

\subsection{Data Collection, Treatment and Analysis}

Information about workers' perceptions about their work context and about their health and experiences of suffering and pleasure were collected through the Inventory of Work and Risks of Illnesses (MENDES, 2007), which the participants were asked to respond.

This inventory consists of four scales: (1) the first allows the identification of workers' evaluation regarding their work context. The subsequent three scales allow the identification of worker's evaluation of: (2) experiences of pleasure and suffering, (3) work-related costs and (4) installed symptoms of illnesses ${ }^{1}$.

The treatment and analysis of the data were performed as follows: Normality tests of the samples were performed; Then, we performed factorial analysis for reduction and grouping the questions that compose each scale into factors. For this we used the factorial adequacy assessment proposed by Kaiser-Meyer-Olkin tests (KMO) and Bartlett's sphericity test, for evaluating the reliability and adequacy of the constructs that make up each factor. To evaluate the reliability, Cronbach's alpha test was performed, with 0,7 as the minimum value for acceptance of adequacy (HAIR et al, 2005). Regressions were then made to identify which variables from of the work context were influencing the reported perceptions of work-related damages (symptoms), as well as their respective explanatory weights (BAUM, 2006; WOLLDRIDGE, 2011).

\subsection{Constitutive definition of research dimensions, factors and variables}

This research aims to identify relations between the following dimensions: (a) "Work Context"; (b) "Subjective Costs of work"; (c) "Experiences of pleasure and suffering at work" and (d) "Damages to workers' health".

1 For complete information about the Inventory of Work and Risks of Illnesses see Mendes (2007). For detailed information on the use of the Inventory of Work and Risks of Illnesses in case studies in the automotive sector see Brüning (2010). 
Each of these dimensions are composed by several variables that were grouped into factors. For this, we performed factor analysis of the scales and used the following statistical tests: The Kaiser-Meyer-Olkin test, an index that compares the magnitudes of the correlation coefficients observed with the magnitudes of partial correlation coefficients. High values, ie above 0.7 to 1.0 indicate that the analysis of variables by factors can be performed. Bartlett's Sphericity Test is another test that indicates the strength of the relationship variables. Values smaller than 0.05 indicate that there are variables that relate to each other differently from the others. In this case, it is also possible to perform the analysis of variables by grouping them into factors. The Cronbach's Alpha test is also used to measure the internal consistency of a given factor. Alpha values above 0.70 are considered satisfactory (HAIR, 2005).

A detailed explanation of each dimension, their variables and grouped factors is presented below:

\subsubsection{Work Context:}

Data collection of worker's perception about current work context at Gama was made by having them respond the scale number 1: "Characterization of the work context", of the Inventory of Work and Risks of Illnesses (MENDES, 2007).

This scale consists of 31 statements, in which the worker is asked to read the items and choose the alternative that best corresponds to the evaluation that he/she makes of his/hers work context, within a Likert scale of 5 points with the following possibilities: (1) never, (2) rarely, (3) sometimes, (4) often, and (5) always.

The statements in scale number 1, 2, 3 and 4 can be found in Portuguese in the work of Mendes (2007) and, translated in to Engligh in a attached table at the end of this paper.

Given the format in which the statements are composed, the higher the score, the worse the assessment that is being made of that aspect of work context.

The 31 statements were treated as independent variables and grouped through factor analysis into 3 factors, as predicted by the model proposed by Mendes (2007), which are: organization of work, working conditions and work relationships. Organization of work comprises the division of labor, the content of the task, the power relations involving the hierarchical system, the modalities of command and the questions of responsibility (MENDES, 2007). Working conditions: include the physical, chemical and biological environment, hygiene, safety conditions and the anthropometric characteristics of the work station (MENDES, 2007). Work relations: refers to all human ties originated in the organization of work, both relations with hierarchy, bosses, supervisors and other workers (MENDES, 2007).

Table 1: Grouped factors of the dimension 1 "Work Context"

\begin{tabular}{|c|c|c|}
\hline $\begin{array}{c}\text { “Organization of Work" } \\
\text { (Factor 1, Dimension 1-F1D1) }\end{array}$ & Statements: 1, 2, 3, 4, 5, 8 and 9 & $\begin{array}{c}\text { KMO: 0,936; } \\
\text { Bartlett's: Sig. 0,000 } \\
\text { Cronbach's Alpha: 0,769 }\end{array}$ \\
\hline $\begin{array}{c}\text { "Work Relations" } \\
\text { (Factor 2, Dimension 1-F2D1) }\end{array}$ & $\begin{array}{c}\text { Statements: 6, 7, 11, 12, 13, 14, } \\
15,16,17,18,19,20 \text { and 21 }\end{array}$ & $\begin{array}{c}\text { KMO: 0,936; } \\
\text { Bartlett's: Sig. 0,000 } \\
\text { Cronbach's Alpha: 0,889 }\end{array}$ \\
\hline $\begin{array}{c}\text { "Working conditions" } \\
\text { (Factor 2, Dimension 1-F3D1) }\end{array}$ & Statements: 22 to 31 & $\begin{array}{c}\text { KMO: 0,936; } \\
\text { Bartlett's: Sig. 0,000 } \\
\text { Cronbach's Alpha: 0,884 }\end{array}$ \\
\hline
\end{tabular}

Source: the authors. 


\subsection{2 "Subjective Costs of work"}

Data collection of worker's perception about the costs that he/she have by working at Gama was made by having them respond the scale number 2 of the Inventory of Work and Risks of Illnesses.

The respondents were asked to choose the alternative that best corresponds to the evaluation he/she makes of the demands arising from his work context. The answers are distributed as a 5-point Likert scale where (1) nothing required (2) little required (3) more or less required, (4) quite required and (5) totally required.

Given the format in which the statements are composed, the higher the score attributed by the worker, the worse is the evaluation attributed.

The 32 statements were treated as independent variables and grouped through factor analysis into 3 factors, as predicted by the model proposed by Mendes (2007), which are: Affective cost, cognitive cost and physical cost, as follows:

Table 2: Grouped factors of the dimension 2 "Subjective costs of work"

\begin{tabular}{|c|c|c|}
\hline $\begin{array}{c}\text { "Affective cost" } \\
\text { (Factor 1, Dimension 2 - F1D2) }\end{array}$ & Statements: 1 to 12 & $\begin{array}{c}\text { KMO: 0,925; } \\
\text { Bartlett's: Sig. 0,000 } \\
\text { Cronbach's Alpha: 0,913 }\end{array}$ \\
\hline $\begin{array}{c}\text { "Cognitive cost" } \\
\text { (Factor 2, Dimension 2 - F2D2) }\end{array}$ & $\begin{array}{l}\text { Statements: } 13 \text { to } \\
22\end{array}$ & $\begin{array}{c}\text { KMO: 0,925; } \\
\text { Bartlett's: Sig. 0,000 } \\
\text { Cronbach's Alpha: 0,899 }\end{array}$ \\
\hline $\begin{array}{c}\text { "Physical cost" } \\
\text { (Factor 3, Dimension 2 - F3D2) }\end{array}$ & $\begin{array}{c}\text { Statements: } 23 \text { to } \\
31\end{array}$ & $\begin{array}{c}\text { KMO: 0,925; } \\
\text { Bartlett's: Sig. 0,000 } \\
\text { Cronbach's Alpha: 0,919 }\end{array}$ \\
\hline
\end{tabular}

Source: the authors.

\subsection{3 "Experiences of pleasure and suffering at work"}

Data collection of worker's perception about the experiences of pleasure and of suffering that he/she have by working at Gama was made by having them respond the scale number 3 of the Inventory of Work and Risks of Illnesses.

The respondents were asked to mark the number of times they have experienced positive and negative feelings the last 6 months at work. The answers are distributed in the form of a Likert scale of 7 points where (0) none, (1) once, (2) twice, (3) three times, (4) four times, (5) five times and (6) six or more times.

Given the format of proposition of the questions we have that for the experience of pleasure, the greater the score attributed by the respondent, the better is the evaluation that he/ she makes of this factor, whereas in relation to the experiences of suffering, the higher the score, indicates a worse assessment of the work environment.

The 32 statements were treated as independent variables and grouped through factor analysis into 4 factors, as predicted by the model proposed by Mendes (2007), which are: "Freedom of expression", "Professional realization", "Experience of suffering" and "Lack of recognition", as follows: 
Table 3: Grouped factors of the dimension 3 "Experiences of pleasure and suffering at work"

\begin{tabular}{|c|c|c|}
\hline $\begin{array}{c}\text { "Freedom of expression" (Factor 1, } \\
\text { Dimension 3-F1D3) }\end{array}$ & Statements: 1 to 8. & $\begin{array}{c}\text { KMO: 0,922 } \\
\text { Bartlett's: Sig. 0,000 } \\
\text { Cronbach's Alpha: } 0,885\end{array}$ \\
\hline $\begin{array}{c}\text { "Professional realization" } \\
\text { (Factor 2, Dimension 3 - F2D3) }\end{array}$ & Statements: 9 to 17 & $\begin{array}{c}\text { KMO: 0,922 } \\
\text { Bartlett's: Sig. 0,000 } \\
\text { Cronbach's Alpha: 0,931 }\end{array}$ \\
\hline $\begin{array}{l}\text { "Experience of suffering" (Factor } \\
\text { 3, Dimension 3-F3D3) }\end{array}$ & Statements: 18 to 20 & $\begin{array}{c}\text { KMO: 0,922 } \\
\text { Bartlett's: Sig. 0,000 } \\
\text { Cronbach's Alpha: } 0,825\end{array}$ \\
\hline $\begin{array}{c}\text { “Lack of recognition” } \\
\text { (Factor 4, Dimension 3 - F4D3) }\end{array}$ & Statements: 21 to 32 & $\begin{array}{c}\text { KMO: 0,922 } \\
\text { Bartlett's: Sig. 0,000 } \\
\text { Cronbach's Alpha: 0,944 }\end{array}$ \\
\hline
\end{tabular}

Source: the authors.

\subsection{4 "Damages to workers' health"}

Data collection of worker's perception about symptoms of illnesses he/she have had working at Gama over the past 6 months was made by having them respond the scale number 4 of the Inventory of Work and Risks of Illnesses.

The respondents were asked to mark the number of times they have experienced different symptoms of illnesses over the last 6 months. The answers are distributed in the form of a Likert scale of 7 points where (0) none, (1) once, (2) twice, (3) three times, (4) four times, (5) five times and (6) six or more times.

Given the format of the scale, it is shown that the higher the score attributed to each question, the higher the incidence of health damage.

The 29 statements were treated as independent variables and grouped through factor analysis into 2 factors, which were named "Physical damage" and "psychosocial damage", as follows:

Table 4: Grouped factors of the dimension 4 "Damages to workers' health"

\begin{tabular}{|c|c|c|}
\hline $\begin{array}{c}\text { "Physical damage" } \\
\text { (Factor 1, Dimension 4-F1D4) }\end{array}$ & Statements: 1 to 12. & $\begin{array}{c}\text { KMO: 0,956 } \\
\text { Bartlett's: Sig. 0,000 } \\
\text { Cronbach's Alpha: 0,922 }\end{array}$ \\
\hline $\begin{array}{c}\text { “Psychosocial damage" } \\
\text { (Factor 2, Dimension 4-F2D4) }\end{array}$ & Statements: 13 to 29. & $\begin{array}{c}\text { KMO: 0,956 } \\
\text { Bartlett's: Sig. 0,000 } \\
\text { Cronbach's Alpha: 0,946 }\end{array}$ \\
\hline
\end{tabular}

Source: the authors.

A report with mean values, number of cases, standard deviation, minimum and maximum values of each of the 12 factors identified for the 4 dimensions presented above is shown in table 5 below: 


\begin{tabular}{lcccccc}
\hline FACTORS: & & Means & N & St. Deviation & Min. Value & $\begin{array}{c}\text { Max. } \\
\text { Value }\end{array}$ \\
\hline F1D1: & "Organization of Work" & 3,7087 & 331 &, 73899 & 1,43 & 5,00 \\
\hline F2D1: & "Work Relations" & 2,6938 & 318 &, 83475 & 1,00 & 4,85 \\
\hline F3D1: & "Working conditions" & 2,4636 & 338 &, 86306 & 1,00 & 5,00 \\
\hline F1D2: & "Affective cost" & 2,1150 & 332 &, 87970 & 1,00 & 5,00 \\
\hline F2D2: & "Cognitive cost" & 3,0728 & 335 &, 94223 & 1,00 & 5,00 \\
\hline F3D2: & "Physical cost" & 3,4553 & 347 & 1,07219 & 1,00 & 5,00 \\
\hline F1D3: & "Freedom of expression" & 2,1992 & 347 & 1,46955 & 0,00 & 5,75 \\
\hline F2D3: & "Professional realization" & 2,1656 & 349 & 1,56221 & 0,00 & 6,00 \\
\hline F3D3: & "Experience of suffering" & 2,5803 & 355 & 1,83313 & 0,00 & 6,00 \\
\hline F4D3: & "Lack of recognition" & 2,0295 & 342 & 1,61146 & 0,00 & 6,00 \\
\hline F1D4: & "Physical damage" & 1,2957 & 350 & 1,48122 & 0,00 & 6,00 \\
\hline F2D4: & "Psychosocial damage" & 1,2260 & 354 & 1,55488 & 0,00 & 6,00 \\
\hline
\end{tabular}

Source: the authors.

\subsection{REGRESSION MODEL APPLIED: CENSORED VARIABLES - TOBIT}

Baum (2006) and Wooldridge (2011) argue that censored data are those in which the dependent variables are contained in a set of arbitrary values in which their values are censored beyond one point. In this research, the dependent variables analyzed are the factors called "physical damage" (F1D4) and "psychosocial damage" (F2D4), both of which are censored for values smaller than zero, that is, all values presented are greater or equal to zero.

Baum (2006) states that a model with data censored at 0 can be expressed in terms of a latent variable $y *$ :

$$
\begin{aligned}
& \mathrm{yi}^{*}=x \mathrm{i} \beta+\text { ui } \\
& y_{i}=\left\{\begin{array}{r}
0, \text { se } y_{i}^{*} \leq 0 \\
y_{i}^{*}, \text { se } y_{i}^{*}>0
\end{array}\right.
\end{aligned}
$$

The Tobit model, according to Baum (2006), should be estimated by maximum likelihood as follows:

$$
\begin{aligned}
l_{i}\left(\beta, \sigma_{u}\right)=I\left(y_{i}=0\right) \log \left\{1-\left(\frac{x_{i} \beta}{\sigma_{u}}\right)\right\}+\ldots \\
\\
\quad \ldots I\left(y_{i}>0\right)\left\{\log \varnothing-\left(\frac{y_{i}-x_{i} \beta}{\sigma_{u}}\right)-\frac{1}{2} \log \left(\frac{\sigma_{u}^{2}}{u}\right)\right\}
\end{aligned}
$$


where I (.) = 1 if the argument is true and zero in other cases. Thus, the maximum likelihood estimates of $\beta$ and $\alpha$ are obtained by maximizing log-likelihood, and can isolate the contribution of censored and uncensored variables from the likelihood function. The marginal effects of the observed variable $y$ are given by:

$$
\frac{\partial E[y \mid x]}{\partial x_{j}}=\beta_{j} X \operatorname{Pr}\left(a<y_{i}^{*}<b\right)
$$

In the following section, the coefficients and marginal effects estimates of each explanatory variable of the model, as well as their theoretical interpretations, are demonstrated.

\section{RESULTS AND ANALYSIS}

As discussed in the previous section, when the range of dependent variables is restricted to the left (in the present case censored for values less than 0 ), a suitable model for regression analysis is the Tobit model. However, the coefficients estimated by such a model, using the maximum likelihood estimator, do not directly represent the marginal relations between the variables, which need to be calculated apart.

First, a regression was performed considering all of the above-mentioned factors (F1D1, F2D1, F3D1, F1D2, F2D2, F3D2, F1D3, F2D3, F3D3, F4D3) as independent variables and the factor F1D4, named "Physical damage" as the dependent variable.

Subsequently, for the same set of independent variables (factors F1D1, F2D1, F3D1, F1D2, F2D2, F3D2, F1D3, F2D3, F3D3, F4D3), we performed a regression considering the factor F2D4, named "Psychosocial damage", as the dependent variable.

The results of both regressions are presented in table 6 and 7 below:

Table 6: Work Context, Subjective Costs of work, Experiences of pleasure and suffering at work and their impact over worker's Physical Health

\begin{tabular}{|c|c|c|c|c|c|}
\hline & $\begin{array}{c}\text { Dependent Variable: factor } \\
\text { F1D4 - "Physical damage" }\end{array}$ & & & & \\
\hline $\begin{array}{c}\text { Variables } \\
\text { (FACTORS) }\end{array}$ & & Coeficient & Marginal Effect & Standard Error & $P$ value \\
\hline F1D1: & "Organization of Work" & -0.006060 & -0.0053939 & 0.100918 & 0.952 \\
\hline F2D1: & "Work Relations" & 0.169691 & 0.1510356 & 0.133065 & 0.204 \\
\hline F3D1: & "Working conditions" & 0.288236 & 0.2565488 & 0.120752 & $\mathbf{0 . 0 1 8}$ \\
\hline F1D2: & "Affective cost" & -0.016297 & -0.0145056 & 0.110619 & 0.883 \\
\hline F2D2: & "Cognitive cost" & 0.004016 & 0.0035750 & 0.088001 & 0.964 \\
\hline F3D2: & "Physical cost" & 0.115161 & 0.1025009 & 0.068443 & 0.094 \\
\hline F1D3: & "Freedom of expression" & -0.119554 & -0.1064109 & 0.052643 & $\mathbf{0 . 0 2 4}$ \\
\hline F2D3: & "Professional realization" & 0.131327 & 0.1168893 & 0.059167 & $\mathbf{0 . 0 2 7}$ \\
\hline F3D3: & "Experience of suffering" & 0.173971 & 0.1548456 & 0.050367 & $\mathbf{0 . 0 0 1}$ \\
\hline F4D3: & "Lack of recognition" & 0.190179 & 0.1692710 & 0.068152 & $\mathbf{0 . 0 0 9}$ \\
\hline Constante & & -0.543029 & & 0.331697 & 0.078 \\
\hline Sigma & & 0.893243 & & 0.042816 & \\
\hline
\end{tabular}




\begin{tabular}{|c|c|l|l|l|l|}
\hline & $\begin{array}{c}\text { Estimates with robust errors for } \\
\text { correction of heteroscedasticity. } \\
\text { White Test 80.6697; P: } 0.090 \\
14 \text { censored remarks to the left } \\
222 \text { uncensored remarks. }\end{array}$ & & & & \\
\hline
\end{tabular}

Source: the authors.

Table 7: Work Context, Subjective Costs of work, Experiences of pleasure and suffering at work and their impact over worker's Psychosocial Health

\begin{tabular}{|c|c|c|c|c|c|}
\hline & $\begin{array}{l}\text { Dependent Variable: factor } \\
\text { F2D4 - "Psychosocial damage" }\end{array}$ & & & & \\
\hline $\begin{array}{l}\text { Variables } \\
\text { (FACTORS) }\end{array}$ & & Coeficient & Marginal Effect & Standard Error & $P$ value \\
\hline F1D1: & "Organization of Work" & 0.018844 & 0.011321 & 0.127817 & 0.883 \\
\hline F2D1: & "Work Relations" & 0.345851 & 0.207787 & 0.174388 & 0.049 \\
\hline F3D1: & "Working conditions" & 0.214475 & 0.128856 & 0.139318 & 0.125 \\
\hline F1D2: & "Affective cost" & 0.047272 & 0.028401 & 0.180202 & 0.793 \\
\hline F2D2: & "Cognitive cost" & -0.186482 & -0.112038 & 0.114169 & 0.104 \\
\hline F3D2: & "Physical cost" & -0.113758 & -0.068345 & 0.098296 & 0.248 \\
\hline F1D3: & "Freedom of expression" & -0.179368 & -0.107764 & 0.080447 & 0.027 \\
\hline F2D3: & "Professional realization" & 0.216298 & 0.129951 & 0.087224 & 0.014 \\
\hline F3D3: & "Experience of suffering" & 0.161368 & 0.096949 & 0.068592 & 0.020 \\
\hline F4D3: & "Lack of recognition" & 0.345059 & 0.207310 & 0.114392 & 0.003 \\
\hline Constante & & & -0.785701 & & 0.510714 \\
\hline Sigma & & & 1.133465 & & 0.070987 \\
\hline & $\begin{array}{l}\text { Estimates with robust errors for } \\
\text { correction of heteroscedasticity. } \\
\text { White Test } 164.047 ; \mathrm{p}: 0,001 \\
54 \text { censored remarks to the left } \\
181 \text { uncensored remarks. }\end{array}$ & & & & \\
\hline
\end{tabular}

Source: the authors.

As stated by Baum (2006), the Tobit model is very sensitive to heteroscedasticity. In both cases the White test for the linear model with MQO estimators indicated the presence of heteroscedasticity, as can be seen in tables 6 and 7. To correct this problem, we used standard robust errors, which in the case, verified that they are normally distributed.

The variables highlighted in bold in table 6 are those that obtained a $p$ value lower than 0.05 , and are therefore considered as factors that present a statistically significant relation with the incidence of physical damage in this sample. Likewise, in table 7, the variables highlighted in bold are those that obtained a $p$ value lower than 0.05 , and are therefore considered as factors that present a statistically significant relation with the incidence of psychosocial damage in this sample.

According to the results of the regressions shown in table 6 , it can be verified that in relation to the physical damages on health, the evaluation factor of the working conditions, which refers to the anthropometric characteristics of the workstation, that is, the ergonomic conditions, provides direct effects. In this case, there is an increase of 0.256 in the average incidence of physical damage, at each point of worsening of the worker's rating scale in relation to these conditions. This allows us to infer a causal nexus between the physical conditions of the workplace and the occurrence of physical symptoms of illness, this being, therefore, the variable that most affects workers' physical conditions.

Empirical evidence of the relationship between working conditions in the automotive industry and the incidence of symptoms of physical illness, such as the incidence of musculoskel- 
etal disorders and hypertension, is not recent, nor is it restricted to the local context of the case under study here, nor even this relation is addressed only in researches inside the Psychodynamics of Work framework.

As an example, international research published since the 1970s already points to this relationship: as is the case of Wisner's work (WISNER, 1995; SZNELWAR, 2006), which analyzes working conditions in French organizations, such as those of the Renault Group, based on an analysis based on Ergonomics, in which he later inserted his theoretical proposal of Anthropotechnology.

As another example we can mention is the research developed by Picoloto and Silveira (2008), a recent research performed with data collected in a Brazil, that identifies musculoskeletal symptoms presented by workers of a metallurgical industry located in the city of Canoas and how this simptoms are related with variables of their work context.

It is also exemplary the work of Jabbour (2011) that, besides also noting these relations, discusses how different theories, from different epistemological approaches, such as the theoretical approaches of Human Resource Management (HRM), Ergonomics, and Psychodynamics of Work recognize the evidence of links between elements of working conditions and their impacts in terms of worker physical health, taking these relationships as object of intervention.

The theory of Psychodynamics of Work theorizes that if it were possible to characterize the health/disease psychodynamics, we would have a continuum in which in one side we would place disease/illness and the other the sensation of psychological well-being, and that the working context allows for a condition of equilibrium between this two extremes. For that equilibrium to happen, two conditions would be necessary: the first being that the intellectual, motor or psychosensory demands of the task were in agreement with the capacities of the individual (DEJOURS, 1974; MENDES, 2007). In relation to the evidence found that there is a statistically significant relationship between the working conditions at the assembly line of the GAMA factories and the incidence of physical symptoms of illness in their workers, one thing that can be argued looking at this evidence from this theoretical framework is that the intellectual, motor and / or psychosensory aspects of work on these assembly lines are beyond the capabilities of their workers.

The second condition for the work context to allow a situation of balance and psychological well-being would be that, in addition to being in accordance with the capacities of the individual, working could also be a source of pleasure (DEJOURS, 1974, MENDES 2007). We found that in the case of GAMA assembly lines, variables regarding experiences of pleasure are also statistically related to the incidence of physical symptoms of illnesses.

The evidence found show that an increase of one unit in the pleasure assessment scale that relates to freedom of expression allows an average reduction of 0.106 cases of incidence of physical symptoms of illnesses. That seems to show that an organizational context in which workers have, or perceive to have, more freedom of expression tends to have a lower incidence of physical illness.

In a counter intuitive way, however, with marginal effect equal to 0.116 , an increase in the evaluation of pleasure related to professional achievement is linked to an increase in the occurrence of physical damages.

In other words, it is noticed that the personal evaluation regarding the experiences of pleasure at work presents ambiguous impacts on the health of the workers when it comes to the incidence of physical symptoms. If, on the one hand, the perception of freedom of expression allows a reduction of the physical damages, on the other hand the perception of professional accomplishment, counter intuitively, elevates such damages. 
How can the theory of Psychodynamics of Work help us to understand the relation that the more professional achievement, the greater incidence of physical symptoms?

It is important to emphasize that the Theory of Psychodynamics of Work points out that suffering is not necessarily a predictor of illness, just as pleasure is not necessarily a predictor of health. An important point of this theory is to recognize that work experience is contradictory, and that the same factor can be a source of pleasure and suffering, pleasure and illness, suffering and health, depending precisely on how the workers inserted in that context experience, interpret, act and defend themselves in relation to these contradictory experiences. Hence the emphasis of this theory on understanding how workers located in a specific empirical field subjectivize their experiences, what meaning they assume for them and what collective strategies they use to account for what is occasioned by the specific context of work they experience (MENDES , 2007).

In the analysis of the health/illness process, one of the main elements is the understanding of the dynamic pleasure/suffering, as well as the defensive strategies before the factors of the organization of work (DEJOURS, 1974, MENDES 2007). Thus, there may be situations where work is, at the same time, a source of pleasure and suffering, transforming into a contradictory experience.

Here, a fundamental concept of Psychodynamics of Work, that can also help us reflect about these phenomena, is the one of Defensive Strategies (MENDES 2007).

Defensive strategies aim at the adaptation of the subject to the pressures of work and can be individual or collective, seeking the promotion of psychic resistance in certain contexts of work. These are psychological mechanisms put in place by workers to decrease the perception of the reality that causes suffering, and therefore is a mechanism that helps the workers cope with suffer. At the same time, it collaborates with the adaptation of workers to their work context. One of its effects, therefore, is the subjection of workers to experiences that causes suffering in a way that they do not remove themselves from that context, nor do something to try and change that context that makes them suffer. This is why, even though defensive strategies helps workers experience less suffering, they may lead to them developing a pathological condition (DEJOURS, 1974, MENDES 2007).

It can be concluded here that perception of professional achievement in the assembly line of the GAMA, although it brings experience of pleasure, is accompanied also by physical illness. To propose from the simple verification of this evidence explanatory hypotheses of why it occurs, from the framework of a theory, would be contradictory with the adopted theory itself, that defends that the experiences of pleasure, suffering and sickness of the workers need to be analyzed and interpreted from its context of reference, and, therefore, goes beyond the contributions that this research can make at the moment. However, we point out the need for future studies that return to this empirical field to investigate with the workers involved with this context how and why this dynamic of pleasure and physical illness related to professional achievement in GAMA occurs.

In addition to the variables related to the experiences of pleasure discussed above, it was also evidenced in the case of the workers of the GAMA assembly lines that variables called "experiencing of suffering" and "lack of recognition" are also correlated with the occurrence of physical damage. In this case, negative evaluation of both factors has a marginal effect in the increased incidence of physical damage. Respectively, the marginal effects are: 0.154 and 0.169 .

In this sense, the theory of Psychodynamics of Work explains that experiences of suffering, such as lack of recognition, are potentially predictors of incidence of illness, and that contradiction or incongruity between the diachronic and synchronic dimensions of the individual in relation to the characteristics of the work context can cause suffering (DEJOURS, 2000), the 
explanatory hypothesis here for the evidence found of the relationship between experiences of suffering and the incidence of symptoms of physical illness, is the one of somatization. Workers may be somatizing questions of their psychic dynamics. Again, this finding of research points to the need to carry out future studies that return to this empirical field to investigate with the workers involved how and why the dynamics of suffering and physical illness occur in GAMA's assembly lines. In relation to the effects on the occurrence of psychosocial damages, as shown in table 7, we verified that results are similar to those observed in relation to the physical damages, occurring changes of magnitude of the marginal effects. The only exception here is that, in this case, the assessment of working conditions does not have statistically significant effects. This result is not surprising, since this variable is linked to the physical effort performed in the work process. Although it was reasonable to observe a significant coefficient, it is expected that the effects would be more likely on physical damage, as suggested by the model. Instead, the aspect of the work context that was shown to have the greater effect on the incidence of psychosocial symptoms are the one called "work relations". This means that the quality of human ties originated in the organization of work, both relations with hierarchy, bosses, supervisors and other workers are the most important antecedent to explain psychosocial symptoms of illnesses, at least in Gama's case. There is an increase of 0.207 in the average incidence of psychosocial damage at each point of worsening of the worker's rating of "work relations".In the course of the historical development of the Psychodynamics of Work theory, the Dejours began to conceive that it is not work that causes illness in people but the way in which this work is organized (DEJOURS, 1974, MENDES 2007). In this sense, this research finding draws attention to the fact that symptoms of psychological and social illness do not appear in the case of GAMA's workers, to be linked to the organization of work, but, instead, they appear to be linked to factors related do interpersonal relations established at work.In an exploratory approach, which aimed to deepen the understanding about this relation in a qualitative, non-systematic way, we performed preliminary interviews with GAMA workers, which lead us to raise an explanatory hypothesis, that here, once again, defense mechanisms are being put into action. The workers with whom we spoke demonstrated a naturalized perception of the work organization as given, natural, immutable. This prevents the workers from perceiving it in a negative or positive way, since they perceive them as "just the way things are". At the same time they attribute their satisfaction/insatisfaction regarding those issues such as pressure for results, established goals, monitoring and surveillance, discontinuity of tasks, among others, not to the way work is organized in GAMA's assembly lines, but to personal relationships they have with their superiors and to personal attributes of their hierarchical superiors, to whom they attribute the ability to act differently from what is established by the work organization. Even though these initial findings may help us to draw some explanatory hypotheses, they are not sufficient to answer questions about how and why the relationships evidenced between work conditions and work relationships appear to be related to the incidence of symptoms of physical and psychosocial illness. Again, we stress here the need for future research that recaptures these questions and deepen this understanding.

\section{RESEARCH CONCLUSIONS AND FINAL CONSIDERA- TIONS}

This research aimed to identify existing relationships between the work context in an organization here named GAMA, inserted in the automobile assembly industry, and the processes of subjectivation of the workers who are part of it. 
The objective was to identify aspects of the work context that might be affecting the incidence of symptoms of illnesses on the work force, both of physical or psychosocial nature.

A few gaps found in the literature review about this subject were considered to justify the objective, theoretical reference and methodological procedures adopted in this research:

In the literature review, it was identified that the understanding about the work context in the automotive sector and its consequences on workers health and subjectivity, although much researched, still has space for the identification of new evidences of relations between these variables.

The literature review also allowed us to identified a great production on the subject within a Psychodynamics of Work theoretical framework, but there were few studies seeking to access the phenomenon from mixed research techniques (qualitative and quantitative methods, as proposed here).

In this sense, a contribution of the research here proposed was the theoretical basis of analysis, which is the Psychodynamics of Work, through which the dynamics of suffering and illness of workers inserted in this context is accessed and analyzed. Although the theory of Psychodinamics of Work is well recognized and accepted in academic circles in Psychology, there is still little research published in the academic area of administration and organizations based on this theory.

Another contribution of this research is the way the Inventory of Work and Illness Risk ITRA was analyzed. As proposed by its authors the analysis of the inventory is limited to the factorial analysis of the scales, with the identification of scores attributed to each factor, in order to identify and compare differences in evaluation of different groups of respondents. In our research, we analyzed de data collected through the Inventory of Work and Illness Risk by searching for relationships between the factors that are formed in the factorial analyses. In the analysis we carried out we performed a new factorial analysis that proved to be confirmatory of that proposed by the creators of the Inventory of Work and Illness Risk (ITRA), and additionally, we performed regression analysis between the factors by using the Tobit regression model, which enable us to identify several relationships between the work context and the incidence of symptoms of illnesses.

The relationships estimated in this article allow us to elaborate some more general conclusions about consequences of working in automotive industrial work context such as GAMA`s: it is possible to identify that the demanding conditions for high physical effort in the work context of an automotive production line are related to the incidence of damage to health, showing itself mostly through symptoms of physical nature. Also it is possible to identify the existence of a relation between subjective experiences of suffering on the incidence of both physical and psychological symptoms of illnesses. One might ask: what does this imply in the practice and management of organizations? How important is this discussion to the world of work? Once analyzing the evidence found, our argument is that, in order to guarantee workers' health, it is not enough to pay attention only to the ergonomic aspects of the work environment. Aspects related to the personal relationships established at work, the experiences of pleasure and suffering that the work provides are also related to the occurrence of symptoms of illness. Responsible organizations concerned with ensuring the health of their workforce should, of course, invest in improving their physical working conditions but also invest in reorganizing the way work occurs, the bonds that occur at work, as well as other subjective aspects related to work.It is important to emphasize that the methodological procedures adopted in this research simply allowed us to identify relationships between variables and factors of the work context and incidence of illness symptoms, but a limitation of the research design adopted here is that explanations about how, and why these identified relationships occur demand further investigations, possibly with another research design, one that complements and explores in greater depth the phenomena here evidenced, that access the speech of the workers themselves about their work context, which 
needs to be done from a qualitative approach that allows explanatory theories to emerge from the perceptions shared by the workers themselves regarding their lives.Therefore this research opens a door for future theoretical and empirical studies that look to understand relationships between psychosocial aspects of the work context and the incidence of symptoms indicative of illness. It is extremely important to understand these relationships, first and foremost to be able to act in a responsible way towards the internal public of the organizations, ensuring that organizations are doing everything that is necessary for employee's health to be protected, and, also, because they have implications for other stakeholders, such as society in general, regulatory agencies, trade unions as well as the public health sector.

\section{REFERENCES}

BAUM, C. F. An introduction to modern econometrics using Stata. College Station, TX. Stata press, 2006.

DEJOURS, C. A banalização da injustiça social. Rio de Janeiro: Ed. FGV, 2000.

DEJOURS, C. A loucura do trabalho. São Paulo: Atlas,1987.

DEJOURS, C. A Loucura do trabalho: estudo de psicopatologia do trabalho. 5a ed. São Paulo: Cortez-Oboré, 1994.

DEJOURS, C. O fator humano. 1a ed. Rio de Janeiro: Editora FGV, 1997.

DEJOURS, C. Travail: usure mentale. De la psychopathologie à la psychodynamique du travail. Paris: Bayard Éditions, 1993.

DEJOURS, C.; ABDOUCHELI, E.; JAYET C. Psicodinâmica do trabalho: contribuições da Escola Dejouriana à nalise da relação prazer, sofrimento e trabalho. São Paulo: Atlas, 1994.

FARIA, J. H. Poder, Controle e Gestão. Curitiba: Juruá Editora, 2017.

FARIA, J. H. Tecnologia e processo de trabalho. Curitiba: UFPR, 1997.

FERREIRA, M; C, MENDES, A. M . Trabalho e riscos de adoecimento - o caso dos auditores-fiscais da previdência social brasileira. Brasília: FENAFISP, 2003.

GIONGO, C. R.; MONTEIRO, J. K.; SOBROSA, G. M. R.. Psicodinâmica do trabalho no Brasil: revisão sistemática da literatura. Temas psicol., Ribeirão Preto, v. 23, n. 4, p. 803-814, dez. 2015.

GUJARATI, D. N.; PORTER, D. C. Econometria básica-5.Porto Alegre. Editora Bookman, 2011.

HAIR, J. et al. Análise multivariada de dados. 5. ed. Porto Alegre: Bookman, 2005.

INSTITUTO EUVALDO LODI. NÚCLEO CENTRAL (IEL/NC). Dinâmica e Tendências do Setor Automotivo - Região Metropolitana de Curitiba. Brasília: IEL/NC, 2009.

JABBOUR, C. J. C. HRM, ergonomics and work psychodynamics: a model and a research agenda. Humanomics, v. 27, n.1, p. 53-60, 2011.

JACQUES, M. G.; O nexo causal em saúde/doença mental no trabalho: uma demanda para a psicologia. Psicol. Soc., Porto Alegre, v. 19, n. spe, p. 112-119, 2007. 
Landisbergis, P.A.; Cahill, J.; Schnall, P. The impact of lean production and related new systems of work organization on worker health. J Occup Health Psychol 1999; 4:108-30.

MACHADO, L. S.; MACEDO, K. B. Análise bibliométrica dos estudos em clínica psicodinâmica do trabalho. Rev. Subj., Fortaleza, v. 16, n. 1, p. 9-23, abr. 2016.

MENDES, A. M. (Org.) Psicodinâmica do trabalho: Teoria, método, pesquisas". 01a ed. São Paulo: Casa do Psicólogo, 2007.

PICOLOTO, D.; SILVEIRA, E.. Prevalência de sintomas osteomusculares e fatores associados em trabalhadores de uma indústria metalúrgica de Canoas - RS.Ciênc. saúde coletiva, Rio de Janeiro, v. 13, n. 2, p. 507-516, Apr. 2008.

PINA, J. A.; NAVARRO STOTZ, E. Intensificação do trabalho e saúde dos trabalhadores: um estudo na Mercedes Benz do Brasil, São Bernardo do Campo, São Paulo. Saúde Soc 2015; 24:82640

PINA, J. A.; NAVARRO STOTZ, E.; JACKSON FILHO, J. M. Trabalhador "compatível", fratura exposta no processo de produção da indústria automobilística: intensificação do trabalho e saúde em questão. Caderno de Saúde Pública, 2018; 34(7). Doi: 10.1590/0102-311X00114017.

RANCAN, M.; GIONGO, C. R. "Nunca pensei sobre isso!": vivências de trabalho na indústria metalmecânica. Cad. psicol. soc. trab., São Paulo, v. 18, n. 1, p. 93-106, 2015.

SOLDERA, L. M. Breve compêndio conceitual e metodológico da Psicodinâmica do Trabalho e da Psicossociologia. Cad. psicol. soc. trab., São Paulo, v. 19, n. 2, p. 243-253, 2016.

Sznelwar, L. I. Alain Wisner: o desenvolvimento da ergonomia e do pensamento sobre o trabalhar. Travailler, vol. 15, no. 1, 2006, pp. 55-70.

TAMAYO, A. Cultura e saúde nas organizações. Porto Alegre: Artmed Editora, 2004.

WISNER. A. A inteligência no trabalho. Textos Selecionados de Ergonomia. São Paulo: Fundacentro, 1995.

WOOLDRIDGE, J. Introdução à econometria: uma abordagem moderna. São Paulo: Cengage Learning, 2011. 


\section{${ }^{*}$ ATACHMENT:}

Description of the statements made in each of the 4 scales of the inventory of work and risks of illness:

\begin{tabular}{|c|c|c|c|}
\hline 1. Work Context Scale & 2.Subjective Costs of work Scale & $\begin{array}{l}\text { 3.Experiences of pleasure and } \\
\text { suffering at work Scale }\end{array}$ & $\begin{array}{l}\text { 4.Damages to workers' } \\
\text { health Scale }\end{array}$ \\
\hline 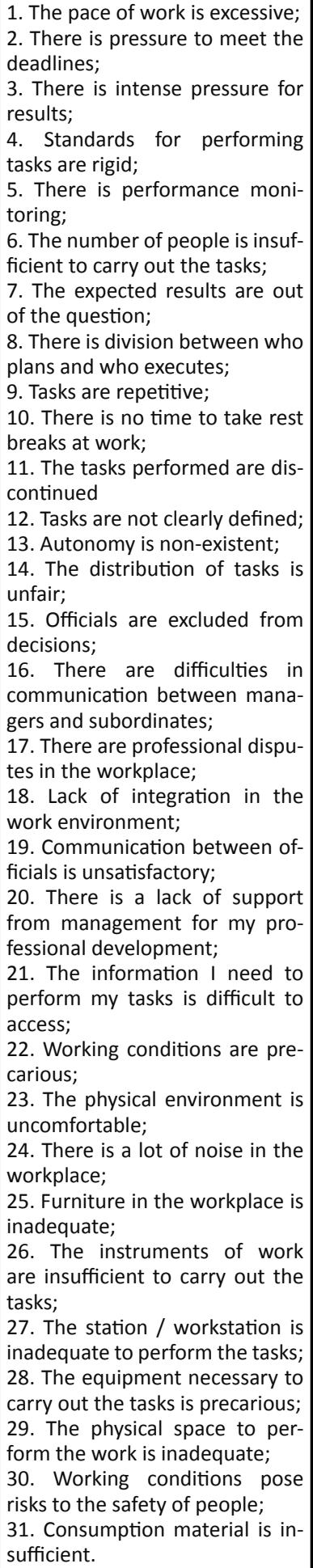 & 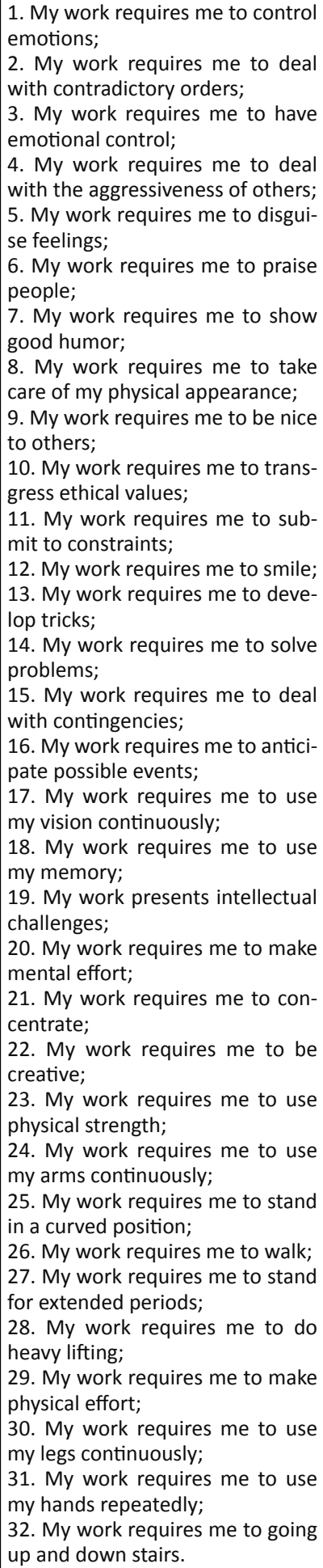 & $\begin{array}{l}\text { 1. Freedom from the leadership } \\
\text { to negotiate what you need; } \\
\text { 2. Freedom to talk about my } \\
\text { work with colleagues; } \\
\text { 3. Solidarity among colleagues; } \\
\text { 4. Trust among colleagues; } \\
\text { 5. Freedom to express my opi- } \\
\text { nions in the workplace; } \\
\text { 6. Freedom to use my creativi- } \\
\text { ty; } \\
\text { 7. Freedom to talk about my } \\
\text { work with the bosses; } \\
\text { 8. Cooperation among collea- } \\
\text { gues; } \\
\text { 9. Satisfaction; } \\
\text { 10. Motivation; } \\
\text { 11. Pride for what I do; } \\
\text { 12. Well-being; } \\
\text { 13. Professional performance; } \\
\text { 14. Appreciation; } \\
\text { 15. Recognition; } \\
\text { 16. Identification with my tasks; } \\
\text { 17. Personal gratification with } \\
\text { my activities; } \\
\text { 18. Emotional exhaustion; } \\
\text { 19. Stress; } \\
\text { 20. Dissatisfaction; } \\
\text { 21. Overload; } \\
\text { 22. Frustration; } \\
\text { 23. Unsafety; } \\
\text { 24. Fear; } \\
\text { 25. Lack of recognition of my } \\
\text { effort; } \\
\text { 26. Lack of recognition of my } \\
\text { performance; } \\
\text { 27. Devaluation; } \\
\text { 28. Indignation; } \\
\text { 29. Ineffectiveness; } \\
\text { 30. Disqualification; } \\
\text { 31. Injustice; } \\
\text { 32. Discrimination }\end{array}$ & $\begin{array}{l}\text { 1. Pain in the body; } \\
\text { 2. Pain in the arms; } \\
\text { 3. Headache; } \\
\text { 4. Respiratory disorders; } \\
\text { 5. Digestive disorders; } \\
\text { 6. Back pain; } \\
\text { 7. Hearing disorders; } \\
\text { 8. Appetite changes; } \\
\text { 9. Vision disturbances; } \\
\text { 10. Sleep disorders; } \\
\text { 11. Pain in the legs; } \\
\text { 12. Circulatory disorders; } \\
\text { 13. Insensitivity towards } \\
\text { colleagues; } \\
\text { 14. Difficulties in rela- } \\
\text { tionships outside work; } \\
\text { 15. Wanting to be alone; } \\
\text { 16. Conflicts in family re- } \\
\text { lations; } \\
\text { 17. Aggression towards } \\
\text { others; } \\
\text { 18. Difficulty with friends; } \\
\text { 19. Impatience with peo- } \\
\text { ple in general; } \\
\text { 20. Bitterness; } \\
\text { 21. Feeling of emptiness; } \\
\text { 22. Feeling of helpless- } \\
\text { ness; } \\
\text { 23. Bad mood; } \\
\text { 24. Desire to give up } \\
\text { everything; } \\
\text { 25. Sadness; } \\
\text { 26. Irritation; } \\
\text { 27. Feeling of abandon- } \\
\text { ment; } \\
\text { 28. Doubt about the abili- } \\
\text { ty to do the tasks; } \\
\text { 29. Loneliness. }\end{array}$ \\
\hline
\end{tabular}


Contribution of authors

\begin{tabular}{|c|c|c|c|}
\hline Contribution & [Author 1] & [Author 2] & [Author 3] \\
\hline $\begin{array}{l}\text { 1. Definition of research } \\
\text { problem }\end{array}$ & $x$ & $x$ & \\
\hline $\begin{array}{l}\text { 2. Development of hypo- } \\
\text { theses or research ques- } \\
\text { tions (empirical studies) }\end{array}$ & $x$ & $x$ & $x$ \\
\hline $\begin{array}{l}\text { 3. Development of theo- } \\
\text { retical propositions } \\
\text { (theoretical work) }\end{array}$ & $x$ & $x$ & \\
\hline $\begin{array}{l}\text { 4. Theoretical foundation } \\
\text { / Literature review }\end{array}$ & $x$ & $x$ & \\
\hline $\begin{array}{l}\text { 5. Definition of metho- } \\
\text { dological procedures }\end{array}$ & $x$ & $x$ & $x$ \\
\hline 6. Data collection & $x$ & & \\
\hline 7. Statistical analysis & $x$ & & $x$ \\
\hline $\begin{array}{l}\text { 8. Analysis and interpre- } \\
\text { tation of data }\end{array}$ & $x$ & & $x$ \\
\hline $\begin{array}{l}\text { 9. Critical revision of the } \\
\text { manuscript }\end{array}$ & $x$ & $x$ & $x$ \\
\hline 10. Manuscript writing & $x$ & & \\
\hline $\begin{array}{l}\text { 11. Other (please spe- } \\
\text { cify) }\end{array}$ & & & \\
\hline
\end{tabular}

